УДК 631.46:631.5:633.63

(C) 2014

Патика М. В., доктор сільськогосподарських наук

Національньний науковий центр «Інститут землеробства НААН»

Москалевська Ю. П., аспірант

(науковий керівник - доктор сільськогосподарських наук М. В. Патика)

Національний університет біоресурсів і природокористування України

\title{
МІКРОБНІ ПРОЦЕСИ ТРАНСФОРМАЦЇ̈ ВУГЛЕЦЮ В РИЗОСФЕРІ БУРЯКА ЦУКРОВОГО ЧОРНОЗЕМУ ТИПОВОГО
}

\section{Рецензент - доктор біологічних наук І. І. Кочевський}

\begin{abstract}
Проведено порівняльний аналіз чисельності за функціональною спрямованістю мікробіоти ризосфери буряка иукрового, щчо бере участь у трансформаиії вуглецю та його сполук, за різних агрозаходів. Визначено вміст органічного та лабільного водорозчинного вуглецю в чорноземі типовому, стан посівів буряка иукрового. Встановлено, щзо локалізація органічних речовин у верхньому кореневмісному шарі трунту сприяє зростанню чисельності мікроорганізмів, які беруть участь у перетворенні вуглецевих сполук у ризосфері культури.
\end{abstract}

Ключові слова: иукровий буряк, ризосфера, мікроорганізми, мультисубстратне тестування, вуглеиь, чорнозем типовий, системи землеробства.

Постановка проблеми. Вуглець - основний структурний елемент живих організмів, що входить до складу всіх органічних сполук. У біосферних механізмах Землі, пов'язаних із біогеохімічними циклами, провідна роль належить кругообігу вуглецю, значну роль у якому відіграють мікроорганізми [9]. Грунт є головним резервуаром вуглецю в біосфері (понад 70 \% вуглецю біосфери міститься у грунтах) і природнім середовищем життєдіяльності мікроорганізмів, які беруть участь у процесах формування й функціонування грунту, а також кругообігу речовин у природі $[7,9,10]$.

Значний вплив на поширення в грунті тих чи інших груп мікроорганізмів мають кореневі ексудати рослин, що є поживним субстратом для мікроорганізмів, які інтенсивно функціонують $\mathrm{i}$ взаємодіють із кореневою зоною рослин [13]. Ризосфера рослин $є$ динамічним біологічним середовищем, у якому діє чимало факторів, що визначають структуру і склад мікробних угруповань, які заселяють ризосферу й ризоплану рослин. Склад мікрофлори ризосфери різних рослин суттєво відрізняється й визначається видом і залежить від стадії розвитку рослин. Дослідження структури й складу цих угруповань $€$ фундамен- тальним завданням для розуміння механізмів впливу на біологічні процеси грунту факторів навколишнього середовища [14].

Аналіз останніх досліджень і публікацій, у яких започатковано розв'язання проблеми. Дослідженнями багатьох вітчизняних і зарубіжних вчених встановлено, що процеси мікробної трансформації вуглецю та його сполук, які відбуваються в грунті, визначають не лише такі його важливі властивості як родючість, біологічна продуктивність, біорізноманіття, але й безпосередньо впливають на характер і напрям глобальних змін біосфери $[1,3-5,7-9]$. Окрім того, поліфункціональність і висока чутливість мікроорганізмів дає змогу реєструвати їх швидку реакціюна зміну характеристик навколишнього середовища і дає можливість оцінити й спрогнозувати стан екосистем у цілому [6].

В умовах підвищеного антропогенного тиску на грунтове середовище, - в зв'язку з інтенсивними технологіями вирощування сільськогосподарських культур - відбуваються зміни в процесах мікробної трансформації вуглецевих сполук, що виражаються у кількісних та якісних перерозподілах у структурі грунтового мікробного комплексу, які не завжди мають позитивний ефект [4]. Тому, зважаючи на актуальність проблеми, метою роботи була оцінка формування мікробного комплексу грунту, що бере участь у трансформації вуглецю, та дослідження особливостей його метаболізму в разі застосування різних агрозаходів.

Завдання досліджень - визначити в ризосфері буряка цукрового чисельність основних функціональних груп мікробіоти, які беруть участь у кругообігу вуглецевих сполук і визначають процеси метаболізму вуглецю, вміст органічного й лабільного водорозчинного вуглецю за різних систем землеробства та способів основного обробітку чорнозему типового.

Матеріали і методи досліджень. Дослідження мікробного комплексу ризосфери буряка цук- 


\section{СІЛЬСЬКЕ ГОСПОДАРСТВО. РОСЛИННИЦТВО}

рового (Beta vulgaris) проводили на базі стаціонарного польового досліду кафедри землеробства та гербології ВП НУБіП України «Агрономічна дослідна станція» в зоні лісостепу в зернобуряковій 10-пільній сівозміні в фазу перед збиранням врожаю буряка цукрового. Грунт дослідних ділянок - чорнозем типовий середньосуглинковий, вміст гумусу в ризосфері - 4,85-5,18\%, $\mathrm{N}_{\text {заг. }}-0,253-0,26 \%, \mathrm{P}_{\text {рухомий }}$ (мінеральні форми) 2,22-2,62 мг в 100 г грунту, $\mathrm{K}_{\text {обмінний }}-7,32-9,45$ мг/100 г грунту, $\mathrm{pH}_{\mathrm{KCl}}-7,43-7,62, \mathrm{pH}_{\mathrm{H} 2 \mathrm{O}}-7,83-$ 7,95, гідролітична кислотність - 0,34-0,45.

Схемою досліду передбачено вивчення двох факторів: системи землеробства на фоні заходів основного обробітку грунту:

1) промислова система землеробства (С3) (контроль) - (застосування на 1 га сівозмінної площі $\mathrm{N}_{92} \mathrm{P}_{100} \mathrm{~K}_{108}$ мінеральних добрив, 12 т гною) + поверхневий обробіток грунту (ОГ) (проведення обробітку дисковими знаряддями на глибину 8-10 см під усі культури сівозміни);

2) промислова система + диференційований обробіток - (проведення за ротацію сівозміни 6 разів різноглибинної оранки, 2 рази поверхневого обробітку під пшеницю озиму після гороху і кукурудзи на силос та 1 раз - плоскорізного обробітку під ячмінь);

3) екологічна система (застосування на 1 га сівозмінної площі $\mathrm{N}_{46} \mathrm{P}_{49} \mathrm{~K}_{55}$ мінеральних добрив, $24 \mathrm{~T}$ органічних добрив (12 т гною, 6 т нетоварної частини врожаю (соломи), 6 т маси пожнивних сидератів (редька)) + поверхневий обробіток;

4) екологічна система + диференційований обробіток;

5) біологічна система (24 т органічних добрив) + поверхневий обробіток;

6) біологічна система + диференційований обробіток [11].

Чисельність мікроорганізмів, які беруть участь у кругообігу основних вуглецевих сполук, визначали методом посіву грунтової суспензії на тверді поживні середовища [5]. Чисельність мікроорганізмів різних функціональних груп, які використовують у своєму метаболізмі джерела вуглецю, визначали методом мультисубстратного тестування [1]. Вміст загального вуглецю - методом Тюріна в модифікації Сімакова [2], лабільний вуглець - методом Шульца і Кершенса [12]. Статистичну обробку результатів досліджень проводили в Ms Excel.

Результати досліджень. Мікробна трансформація органічних сполук, основну масу яких займають целюлоза, геміцелюлоза, пектин, крохмаль, хітин, ліпіди, лігнін, гумусові сполуки тощо, має значення в грунтоутворювальних проце- сах, мінералізації та кругообігу вуглецю, в т. ч. структуруванні й утворенні гумусових речовин та поверненні основної маси $\mathrm{CO}_{2}$, необхідної для дифузії з атмосферою [5].

Дослідженнями встановлено, що чисельність мікроорганізмів, які беруть участь у кругообігу вуглецю, варіювала в межах 0,86-10,29 млн. КУО/1 г. а. с. г., основну частку яких становили бактерії (рис. 1).

Кількісний склад мікроорганізмів, що трансформують целюлозу становив 3,05-4,91 млн КУО/1 г.а.с.г., геміцелюлозу - 2,85-5,83 млн, частка стрептоміцетів серед трансформаторів геміцелюлози становила 36,1-59,7 \%. Найбільша чисельність зазначених мікроорганізмів була виявлена за біологічної С3 - 4,00-4,07 млн і 4,685,48 млн відповідно, за екологічної С3 відбувалось зниження кількості трансформаторів целюлози і геміцелюлози на 1,3\% і 17 \%, за промислової С3 - на 2,6 \% і 19,7\%. Встановлено, що застосування поверхневого обробітку грунту ОГ сприяє зростанню чисельності мікроорганізмів, які беруть участь у трансформації целюлози, на $23,9 \%$ і геміцелюлози - на 33,6 \% за рахунок локалізації у верхньому кореневмісному шарі грунту рослинних решток.

Чисельність мікробіоти, що бере участь у трансформації пектину, була 2,03-6,00 млн. КУО/1 г.а.с.г, 71,3-85,5 \% якої становили бактерії, 8,5-16,4 \% стрептоміцети та 3,2-16,7 \% - мікроміцети. Найменше мікроорганізмів, що розкладають пектин (2,03 млн), виявлено в разі застосування біологічної С3 у поєднанні 3 диференційованим ОГ, найбільше - за екологічної С3 із поверхневим ОГ (6,00 млн). Чисельність мікроорганізмів, трансформуючих крохмаль, варіювала в межах 2,75-10,29 млн, до того ж характер зон навколо колоній мікроорганізмів вказував на те, що гідроліз пройшов до стадії утворення цукру. Найактивніше процеси трансформації крохмалю відбувалися за промислової С3, найменш активно - за біологічної С3 (втричі менше). Застосовуючи поверхневий ОГ також зростає чисельність мікроорганізмів, що трансформують пектин і крохмаль, на 17,4 \% і 39,7 \% відповідно.

Кількість мікроорганізмів, що беруть участь у трансформації хітину, варіював у межах 1,10-3,82 млн. КУО/1 г.а.с.г., найбілыше їх було виявлено у варіанті досліду біологічна С3 + диференційований ОГ (3,82 млн), найменше - промислова С3 + поверхневий ОГ (1,10 млн). Чисельність ліпідтрансформуючої мікрофлори становила 0,86-1,07 млн. Найбільше мікроорганізмів, що перетворюють ліпіди і хітин, було виявлено за біологічної С3 0,95-1,07 та 3,09-3,82 млн. 


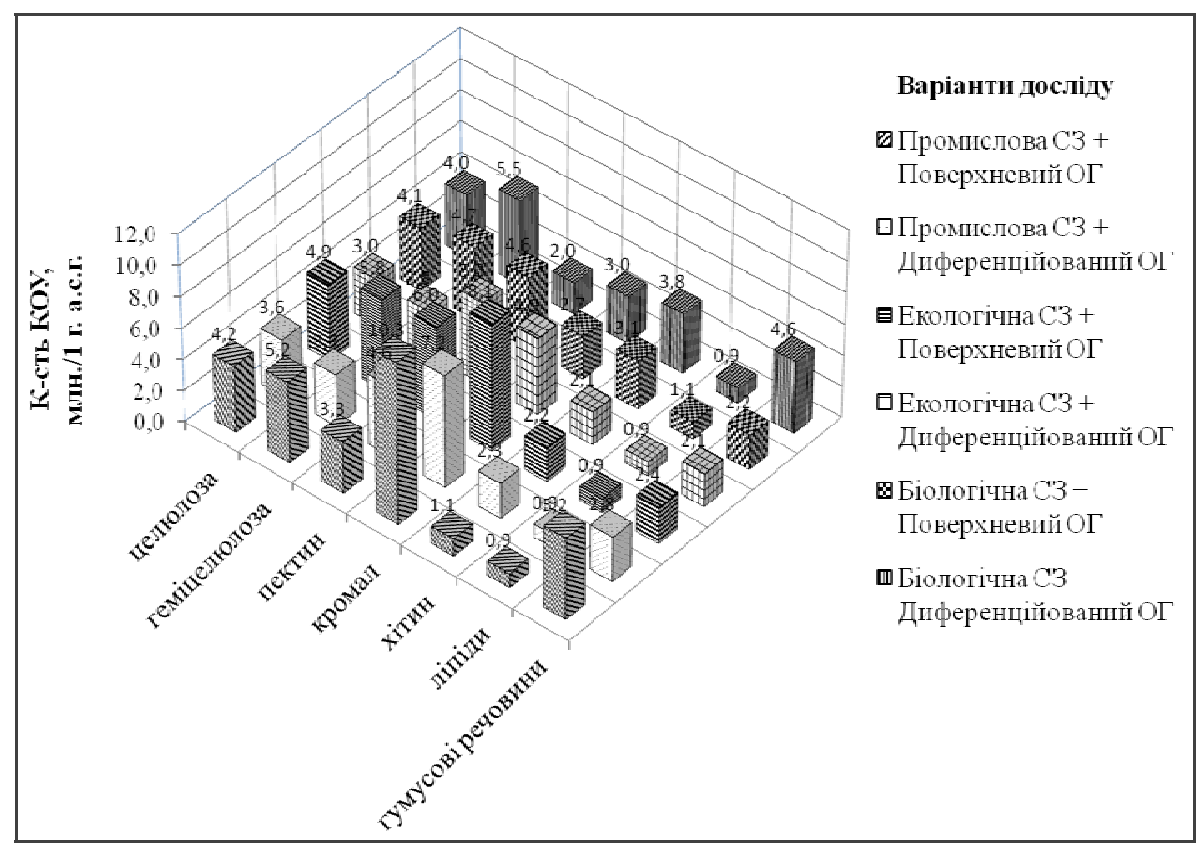

\section{Рис. 1. Чисельність мікроорганізмів ризосфери буряка цукрового, які беруть участь у кругообігу вуглецевих сполук}

За екологічної С3 чисельність мікробіоти була нижчою на 12,8 та 60,2 \%, промислової С3 - на $15,4 \%$ і в два рази відповідно. За поверхневого ОГ кількісний склад мікроорганізмів, що беруть участь у перетворенні жирів, був вищим на $5,8 \%$, а хітину, навпаки, нижчим на $28,7 \%$, що пов'язано зі збільшенням біомаси грибів та хітин-вмісних рештків макрофауни в кореневмісному шарі чорнозему.

Чисельність мікробіоти, яка бере участь у трансформації гумусових речовин, становила 2,135,21 млн КУО/1 г.а.с.г. До того ж, більше мікроорганізмів виявлено за промислової С3 (5,21 млн за поверхневого і 2,84 млн - за диференційованого ОГ), найменше - за екологічної С3 (2,36 млн і 2,13 млн відповідно). У разі поверхневого ОГ чисельність мікрофлори була вищою на 2,2 \%, ніж при диференційованому ОГ. Тобто, локалізація органічних речовин у верхньому шарі грунту сприяє (в різній мірі) зростанню чисельності активної мікробної складової грунту, що бере участь у кругообігу вуглецевих сполук.

Метаболізм різних вуглецьвмісних сполук у грунті відбувається неоднаково внаслідок відмінності їх структури й значного біорізноманіття мікрофлори, яка використовує в своєму метаболізмі джерела вуглецю [10]. Мультисубстратним тестуванням встановлено, що сумарна чисельність функціональних груп мікроорганізмів була більшою на субстратах із триптофаном $(1,48$ млн КУО/1 г.а.с.г.) і лимонною кислотою (1,41 млн) (рис. 2, 3). Сумарна чисельність мікроорганізмів, які використовують у своєму метаболізмі джерела вуглецю, була на 4 \% вищою за використання диференційованого ОГ, порівняно 3 поверхневим. Кількісний склад мікробіоти, яка використовує в своєму метаболізмі джерела вуглецю, був вищим на 32,5 і $51,7 \%$ за біологічної C3, ніж за промислової та екологічної С3. Таким чином, використання органічних добрив сприяє підтриманню й збереженню еколого-трофічних зв'язків і високої функціональної активності мікроорганізмів грунту.

Відомо, що чорноземи характеризуються кращими показниками якості грунту, які зумовлюють їх родючість, порівняно з іншими грунтами. Встановлено, що вміст загального вуглецю в ризосфері буряка цукрового був високим і становив 2,81$3,00 \%$ (табл. 1). За біологічної та промислової С3 запаси органічного вуглецю були вищі на 3 \%, порівняно з екологічною СЗ. Застосування поверхневого ОГ сприяє накопиченню на 3,5 \% більше $\mathrm{C}_{\text {орг. }}$ у грунті, ніж за диференційованого. За вмістом лабільного водорозчинного вуглецю чорнозем типовий характеризується оптимальними показниками - 306,82-350,68 мг/кг (табл. 1). За біологічної та екологічної С3 запаси лабільного вуглецю були вищі на 6,4 та 5,7 \% порівняно з його вмістом за промислової С3. Застосування поверхневого ОГ сприяє накопиченню $\mathrm{C}_{\text {лаб }}$ У ризосфері буряка цукрового на 6,9 \% більше, ніж за диференційованого ОГ. 


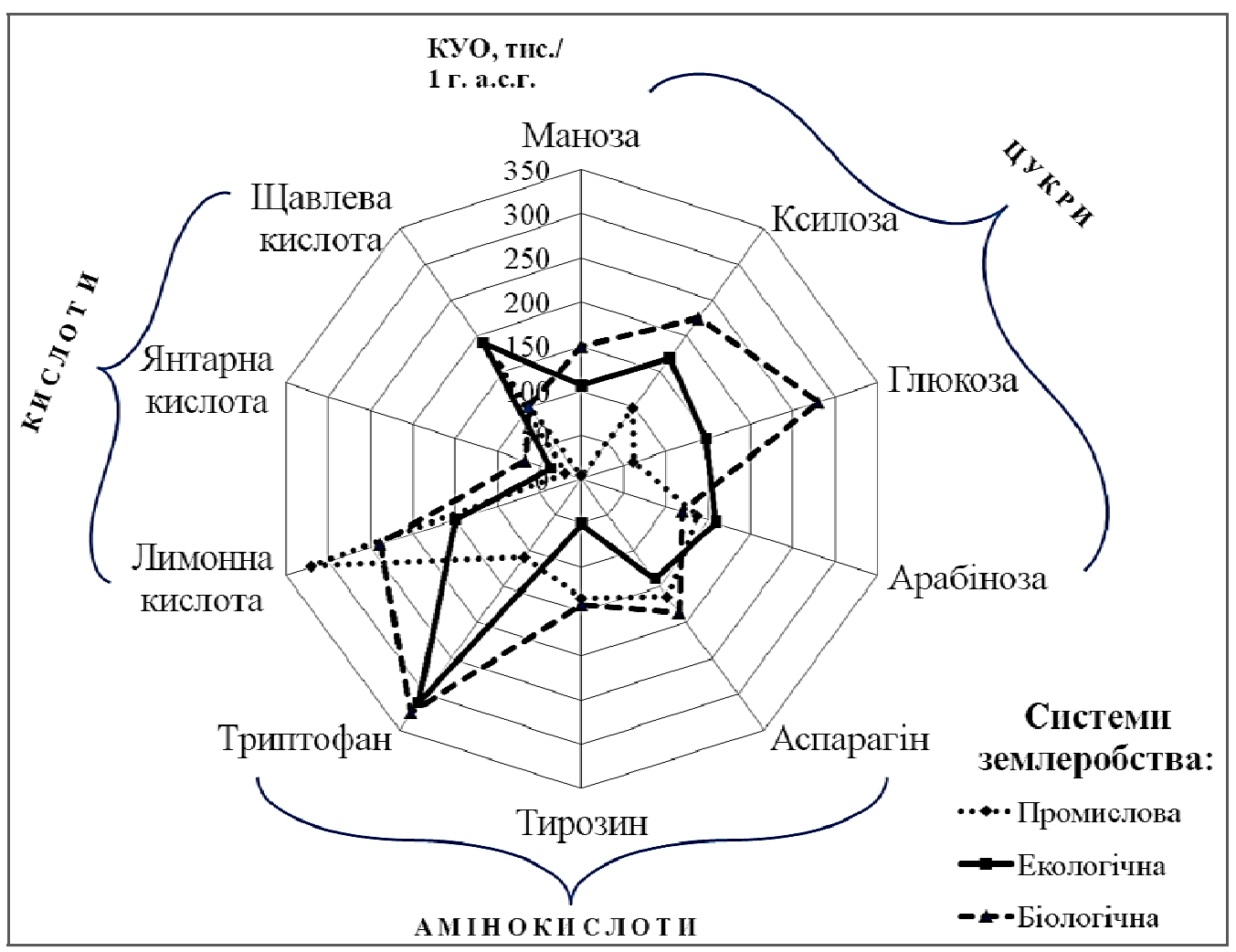

Рис. 2. Чисельність функціональних груп мікроорганізмів, які використовують джерела вуглецю, за поверхневого ОГ

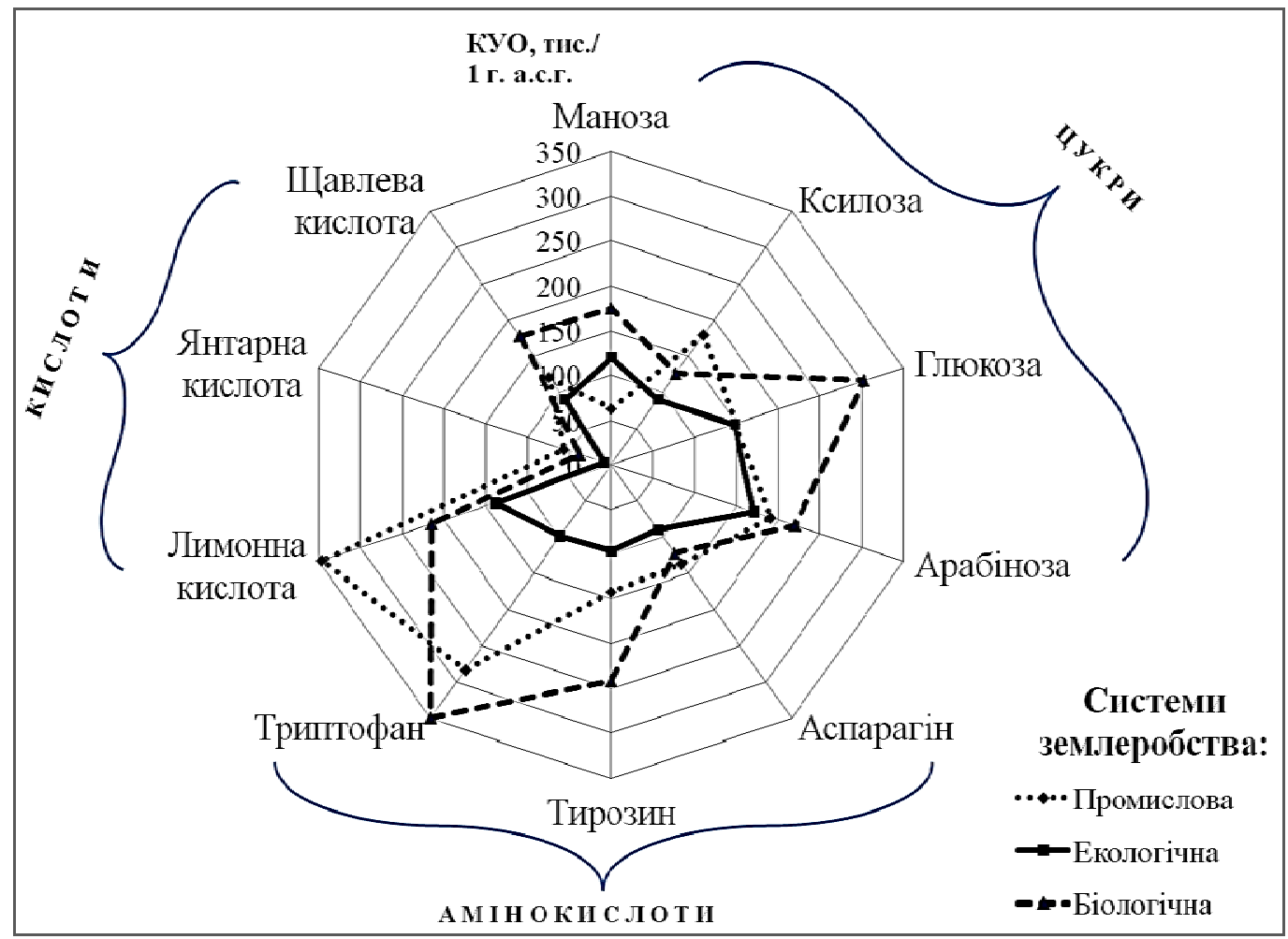

Рис. 3. Чисельність функціональних груп мікроорганізмів, які використовують джерела вуглецю, за диференційованого ОГ 
СІЛЬСЬКЕ ГОСПОДАРСТВО. РОСЛИННИЦТВО

\section{1. Вміст органічного і лабільного вуглецю в трунті залежнно від систем землеробства}

\begin{tabular}{|c|c|c|c|c|c|c|}
\hline \multirow{2}{*}{$\begin{array}{c}\text { Варіант } \\
\text { досліду }\end{array}$} & \multicolumn{2}{|c|}{ Промислова С3 } & \multicolumn{2}{c|}{ Екологічна С3 } & \multicolumn{2}{c|}{ Біологічна С3 } \\
\cline { 2 - 7 } & пов. ОГ & диф. ОГ & пов. ОГ & диф. ОГ & пов. ОГ & диф. ОГ \\
\hline Вміст С орг., $\%$ & 2,97 & 2,88 & 2,89 & 2,81 & 3,00 & 2,87 \\
\hline $\mathrm{C}_{\text {лаб., мГ кГ }}$ & 321,47 & 306,82 & 341,13 & 323,00 & 350,68 & 318,22 \\
\hline
\end{tabular}

2. Біометричні показники буряка цукрового

\begin{tabular}{|c|c|c|c|c|c|c|c|c|}
\hline \multirow{2}{*}{\multicolumn{2}{|c|}{ Варіант досліду }} & $\mathrm{L}$ & $\mathrm{H}$ & $\mathrm{L}$ & $\mathrm{H}$ & \multirow{3}{*}{$\begin{array}{c}\text { М } \\
\text { корене- } \\
\text { плоду, } \\
\text { кг }\end{array}$} & \multirow{3}{*}{$\begin{array}{l}\text { S лист- } \\
\text { кової } \\
\text { плас } \\
\text { тинки, } \\
\text { см }^{2}\end{array}$} & \multirow{3}{*}{$\begin{array}{c}\text { Індекс спів- } \\
\text { відношення } \\
\text { площі листової } \\
\text { пластинки } \\
\text { до площі } \\
\text { коренеплоду }\end{array}$} \\
\hline & & \multicolumn{2}{|c|}{ коренеплоду } & \multicolumn{2}{|c|}{$\begin{array}{l}\text { листкової } \\
\text { пластинки }\end{array}$} & & & \\
\hline & & \multicolumn{4}{|c|}{$\mathrm{cm}$} & & & \\
\hline \multirow{2}{*}{ Пром. С3 } & пов. ОГ & 35,9 & 16,0 & 41,4 & 11,3 & 2,35 & 509,2 & 0,89 \\
\hline & диф. ОГ & 38,1 & 14,1 & 40,4 & 11,2 & 1,81 & 453,3 & 0,84 \\
\hline \multirow{2}{*}{ Екол. С3 } & пов. ОГ & 29,0 & 14,0 & 44,1 & 13,6 & 1,49 & 600,3 & 1,48 \\
\hline & диф. ОГ & 36,8 & 14,3 & 36,0 & 11,2 & 1,72 & 405,2 & 0,77 \\
\hline \multirow{2}{*}{ Біол. С3 } & пов. ОГ & 34,7 & 12,3 & 43,0 & 11,6 & 1,36 & 427,6 & 0,58 \\
\hline & диф. ОГ & 33,8 & 12,6 & 41,6 & 13,6 & 1,63 & 566,8 & 1,61 \\
\hline \multicolumn{2}{|c|}{ HIP, $5 \%$} & 5,90 & 3,57 & 5,80 & 3,01 & 3,01 & & \\
\hline
\end{tabular}

Інтегральними показниками, за якими оцінюють вплив агротехнічних заходів на родючість грунту й визначають продуктивність сільськогосподарських культур є біометричні показники рослин (табл. 2). Найбільша площа листкової пластинки була у варіанті екологічна С3 + поверхневий ОГ $\left(600,3 \mathrm{~cm}^{2}\right)$, а найбільша маса коренеплоду отримана за промислової С3 у поєднанні 3 поверхневим ОГ (2,35 кг). Загалом площа листкової пластинки була більшою на 7,8 \% за поверхневого ОГ, аніж за диференційованого, а на масу коренеплоду спосіб обробітку не впливав. За системами землеробства маса коренеплоду зі зменшенням норми внесення мінеральних та органічних добрив зменшувалася. Площа листкової пластинки на $4,5 \%$ та $1,1 \%$ більша була в разі застосування екологічної С3, порівняно 3 промисловою та біологічною С3.

Висновок. Таким чином, у ризосфері буряка цукрового за різних агрозаходів формуються специфічні для даної культури мікробоценози 3 неоднаковою чисельністю мікроорганізмів, які

\section{БІБЛІОГРАФІЯ}

1. Горленко М. В. Мультисубстратное тестирование природных микробных сообществ / М. В. Горленко, П. А. Кожевин. - М. : МАКС, Пресс, 2005. -88 c.

2. Городній М. М. Агрохімічний аналіз / М. М. Городній, А. В. Бикін, А. Г. Сердюк [та ін.]. - К. : беруть участь у перетворенні вуглецю, відбувається перерозподіл функціональної активності мікробної складової, що, в свою чергу, сприяє зміні направленості мікробних метаболічних процесів перетворення вуглецевих сполук. Встановлено, що застосування лише органічних добрив сприяє збільшенню чисельного складу мікробіоти, яка бере участь у кругообігу геміцелюлози, хітину та ліпідів у 1,13-2,05 рази, а також трансформації цукрів (манози, ксилози, глюкози), амінокислот (аспарагіну, тирозину, триптофану) та щавлевої кислоти в 1,26-4,9 разу, порівняно $з$ екологічною та промисловою С3.

Локалізація органічних речовин у верхньому шарі грунту зумовлює збільшення вмісту лабільного вуглецю на $6,9 \%$ і органічного вуглецю на $3,5 \%$ у ризосфері буряка цукрового та зростанню чисельності активної мікробної складової грунту, що бере участь у кругообігу вуглецевих сполук, на 2,2-39,7\%. Застосування інтенсивної (промислової) технології вирощування культур сприяло збільшенню маси підземної частини буряка цукрового на 29,7-37,5 \%.

Арістей, 2007. - 624 с.

3. Іутинська Г. О. Грунтова мікробіологія. - К. : Арістей, 2006. - 284 с.

4. Круглов Ю. В. Изменение агрофизических свойств и микробиологических процессах дерново-подзолистой почвы в экстремальных усло- 


\section{СІЛЬСЬКЕ ГОСПОДАРСТВО. РОСЛИННИЦТВО}

виях высокой температуры и засухи / Ю. В. Круглов, М. М. Умаров, Н. В. Патыка // Известия ТСХА. - 2012. - Вып. 3. - С. 79-87.

5. Методы почвенной микробиологии и биохимии: Учеб. пособие / Под ред. Д. Г. Звягинцева. - М.: Изд-во МГУ, 1991. - 304 с.

6. Минаева E. C. Влияние полевок (Microtus rossiaemeridionalis и Clethrionomys glareolus) на биологическую активность почв: автореф. дис. канд. биол. наук: спец. 03.02.08 «Экология», 03.02.13 «Почвоведение» / Е. С. Минаева. - М., 2013. - $26 \mathrm{c}$.

7. Патыка Н. В. Профиль полиморфизма длин рестрикционных фрагментов комплекса прокариотных микроорганизмов подзолистых почв / Н. В. Патыка, Ю. В. Круглов, И. А. Тихонович [и др.] //Доповіді Національної академії наук України. - 2009. - № 1. - С.187-192.

8. Патыка Н. В. Исследование дерново-подзолистых почв при возделывании льна-долгунца в сверхдлительном опыте / Н. В. Патыка, Ю. В. Круглов, М. А. Мазиров [и др.] // Корми і кормовиробництво. - 2008. - Вип. 62. - С. 258-268

9. Помазкина Л. В. Устойчивость агроэкосистем к загрязнению фторидами / Л.В. Помазкина, Л. Г. Котова, Е. В. Лубнина [и др.] - Иркутск,
Из-дво института географии СО РАН, 2004. - 225 с.

10. Сидоренко О. Д. Микробиология / О. Д. Сидоренко, Е. Г. Борисенко, А. А. Ванькова, Л. И. Войко. - М., 2005. - 287 с.

11. Танчик С. П. Екологічна система землеробства в Лісостепу України. Методичні рекомендації для впровадження у виробництво / С. П. Танчик, О. А. Демідов, Ю. П. Манько. - К.: НУБІП України, 2011. - 39 с.

12. Шульи Э. Характеристика разлагаемой части органического вещества почвы и ее трансформации при помощи экстракции горячей водой / Э. Шульц, М. Кершес // Почвоведение. 1998. - № 7. - C. 890-894.

13. Davey M. E. Microbial biofilms: from ecology to molecular genetics / M. V. Davey, G. A. O'toole // Microbiology and molecular biology reviews. -2000 . - T. 64. - №. 4. - P. 847867.

14. Lupwayi N. Z. Soil microbial diversity and community structure under wheat as influenced by tillage and crop rotation / N. Z. Lupway, W. A. Rice, G. V. Clayton // Soil Biology and Biochemistry. - 1998. - T. 30. - №. 13. - P. 17331741 . 